\title{
A Case Study on the Ayurvedic Managment of Spastic Cerebral Palsy Due to Birth Asphyxia
}

\author{
Srivastava Kumar Niraj' and Saxena Varsha ${ }^{2 *}$ \\ 'Department of Kaumarbhritya /Bal-roga, Government Ayurvedic P. G. College and Hospital, (Sampurnanand \\ Sanskrit University), Varanasi - 221001, Uttar Pradesh, India; nirajimsbhu@gmail.com \\ 2Department of Shalya-tantra, Main campus, Uttarakhand Ayurveda University (UAU), Dehradun - 248001, \\ Uttarakhand, India; drvarshasaxena2015@gmail.com
}

\begin{abstract}
Background: Cerebral palsy is a disorder of motor control due to a static lesion of the developing brain. It was described almost 150 years ago. Global incidence of Cerebral Palsy is 2 to 2.5/1000 children but in Indian scenario, incidence is 03.8\% of population. In India about twenty-five Lakh children are suffering from cerebral palsy. Most common type of cerebral palsy is spastic which cover $70 \%$ to $75 \%$ of overall. There is no exact correlation found for cerebral palsy in Ayurvedic literature but may be the result of Shiromarmabhighata (injury to brain) and can be considered as Vata Vikara or Vata Vyadhi (neurological disorders). Aim: To assess the effect of certain oral medication with Purvakarma (preparatory procedures) and Panchakarma procedures (Five-fold measures of Bio-cleansing) in the management of Cerebral Palsy (CP). Material and Method: In this case study, one case of Spastic cerebral palsy was registered and treated with multiple Ayurvedic treatment modalities. Total period of treatment was 93 days in which 5 days of Abhyanga (Massage) with Nadi swedana (steam kettle Sudation), 5 days of Abhyanga (Massage) with Shashti Shali Pinda Swedana (a type of Sudation) and then 7 days of Matra Vasti (Enema by Medicated oil in small dose) by Ksheera Bala Taila; this schedule of treatment was given three times with a gap of 14 days. Vacha mula (Root of Acorus calamus) and Samvardhana Ghrita was given as internal medication during the total course of treatment. Results were assessed by progress in delayed milestone, anthropometrical measurement, modified Ashworth scale, muscle power grading and Manual Ability Classification System (MACS) scale. Result: Treatment protocol of oral medication with Panchkarma delivered better result in CP patient, especially improving anthropometric data (weight, height, chest circumference), delaying milestone (walking and language), reducing spasticity and improved Quality of Life (QOL). Conclusion: Cerebral palsy is a disorder of motor function. The cause originates from the brain sometime during its developmental period. Internal medication along with Purvakarma (preparatory procedures) and Panchakarma (Five-fold measures of Bio-cleansing) give significant improvement in all the facets of spastic CP.
\end{abstract}

Keywords: Abhyanga, Matra-Vasti, Samvardhana Ghrita, Vata Vyadhi

\section{Introduction}

$\mathrm{CP}$ is motor function disorder and first described by William Little (1810-1894) in the $1840 s^{1}$. Most important cause of chronic disability in children is $\mathrm{CP}^{2}$ and making them physically handicapped, mentally handicapped and socially detached ${ }^{3}$. Cerebral palsy is linked with convulsion, abnormalities in language, visualization and intelligence due to hypoxia in developing brain ${ }^{4}$, during prenatal, natal and postnatal period of life $e^{5}$. Global incidence of Cerebral Palsy is 2 to $2.5 / 1000$ live births ${ }^{6}$ but in India, incidence is $03.8 \%$ of the population ${ }^{7}$. Currently, in India about 2.5 million children are suffering from cerebral palsy ${ }^{8}$. The World Health Organization (WHO) estimates that, about $10 \%$ of the overall population suffers from physical and mental disorder ${ }^{9}$. Indian data shows that $3.8 \%$ of the population suffers from various type of disability in India ${ }^{10}$. Almost $15-20 \%$ of total

*Author for correspondence 
physical handicapped children suffer from various type of cerebral palsy ${ }^{11}$.

Motor disorders of $\mathrm{CP}$ are frequently associated with disorder of communication, behavior, sensation, perception and cognition. CP is divided into four types and most common type of cerebral palsy is spastic which cover $70 \%$ to $75 \%$ of overall cases ${ }^{12}$. Common causes of cerebral palsy are brain insult due to prematurity, birth asphyxia, hypoxic ischemic encephalopathy, meningitis and accidental head trauma. Modern medicine has no cure for any types or subtypes of cerebral palsy. Much newer advancement is being tried for treatment of cerebral palsy and associated features such as therapeutic hypothermia therapy ${ }^{13}$, Botulinum toxin injection ${ }^{14}$, Baclofen injection ${ }^{15}$, hyperbaric oxygen therapy ${ }^{16}$, selective dorsal rhizotomy ${ }^{17}$, neuroplasticity ${ }^{18}$ and stem cell transplantation procedure.

There is no exact correlation found for $\mathrm{CP}$ in Ayurvedic literature. However, in view of the etiology and clinical feature, Cerebral Palsy may be the result of Shiromarmabhighata (injury to brain) and can be considered as Vata Vikara (neurological disorders) ${ }^{19,20}$. Various conditions like Phakka (nutritional disorder) ${ }^{21}$, Pangulya (locomotory disorders), Mukatva (Speech or language disorder), Jadatva (inability to do motor activities), Pakshaghata (hemiparesis), Ekangaroga (monoplegia) $^{22}$ Sarvangaroga (quadriplegia) ${ }^{23}$ etc. exhibits signs and symptoms of Cerebral palsy where the main Dosha involved is Vata. Hence, CP should be treated on guideline of Vata Vikara or Vata Vyadhi (neurological disorders). In this case study, the effect of Ayurvedic therapy protocol for improving the condition of a spastic cerebral palsy patient was evaluated. The outcome of this clinical study will reveal further regarding the effect of these treatment modalities in the management of spastic cerebral palsy due to brain insult.

\section{Case Report}

\subsection{Basic Information of the Patient}

Age: 5 years

Sex: Male

Religion: Hindu

Socioeconomic Status (SES): Lower class.
Father has studied $10^{\text {th }}$ standard and currently working as a security guard, mother is house wife.

\subsection{Chief Complaints}

- Unable to walk

- Spasticity of body

- Poor coordination

- All milestones are delayed since infantile age

\subsection{History of Present IIIness}

A 5.0 years old male child brought by his parents to Kaumarbhritya OPD of Government Ayurvedic PG College Varanasi with above complaints. According to Patient baby was delivered by LSCS (lower segment cesarean section) prematurely, and suffered from Hypoxic Ischemic Encephalopathy (HIE) and neonatal jaundice. Spasticity and involuntary movement became noticeable after the age of 5 months and then parent started treatment by many allopathic doctors without any significant benefit. At the age of five years they approached us for further management.

\subsection{History of Past}

Hypoxic Ischemic Encephalopathy (HIE) grade-2 and neonatal jaundice.

\subsection{Treatment History}

Child was treated by many allopathic doctors and the treatment details are as mentioned below;

1. Anti-convulsanttherapyforfirst 2 years(Phenobarbitone)

2. Tablet Baclofen for muscle relaxant.

3. Botox injection to reduce contractures.

4. Physiotherapy

\subsection{Family history}

Family history is not significant.

\subsection{Birth History}

At the time of delivery, age of mother was 21 years and has not suffered from any disease. According to patient, 
baby was delivered by LSCS and indication of LSCS was fetal distress. Baby did not cry after birth and weak cry start after 24 hrs. Baby was shifted to NICU (Neonatal intensive care unit) for proper care and management. Data of APGAR score and resuscitation measures taken was not available. Baby was delivered prematurely (34 weeks) and at the time of birth weight of baby was $1.6 \mathrm{~kg}$ (low birth weight).

\subsection{Vaccination history}

Proper for age.

\subsection{Personal History}

Patient was totally dependent for food intake and activity. Patient was eating only semi solid food due to lack of coordination in deglutition. Appetite of patient was very poor and frequently suffers from cough and cold. Sleep was disturbed, bed wetting (not achieved bladder control) and drooling from the mouth since birth.

\section{Examination}

Vitals of patient were normal. Examination of cardiovascular system, respiratory system and gastro intestinal system had not shown any abnormality.

\subsection{Central Nervous System (CNS) Examination}

- Patient was hypertonic (spasticity) and suffers from mild contractures at ankle and knee joint.

- Muscle power was in grade one.

- Cranial nerve examination- Not done (Due to handicapped physical and mental state of the patient.
- Hyper-reflexia was present (Suggest upper motor neuron (UMN) injury which is main characteristic of cerebral palsy.

- Babinski sign - Present

- Meningeal signs - Absent (Neck rigidity, Kernig sign and Brudzinski sign were not present)

\section{Investigations}

CT scan and MRI were taken to identify anatomical abnormality in the region of brain. In this case impression of MRI is Spastic CP with sequels of HIE (Hypoxic ischemic encephalopathy).

\section{Material and Method}

In this case study one case of Spastic cerebral palsy was registered and treated with multiple Ayurvedic treatment modalities. Total period of treatment is 93 days in which 5 days of Abhyanga (Massage) with Nadi swedana (steam kettle Sudation), 5 days of Abhyanga (Massage) with Shashti Shali Pinda Swedana (a type of Sudation) and then 7 days of Matra Vasti (Enema by Medicated oil in small dose) by Ksheera Bala Taila. Vacha mula (Root of Acorus calamus) and Samvardhana Ghrita was given during the entire duration of treatment as internal medication.

\section{Treatment Protocol}

\section{Criteria for Assessment}

The assessment was done on the basis of improvement in delayed milestones, growth parameters, drooling

\begin{tabular}{|c|c|c|}
\hline \multicolumn{3}{|c|}{ Step - 1 Oral medication (Total 93 days) } \\
\hline 1. & $\begin{array}{l}\text { Vacha-mula } \\
\text { (Root of } \text { Acorus calamus) } \\
\text { (Duration=93 days) }\end{array}$ & $\begin{array}{l}\text { It was rubbed } 40 \text { times on a stone in } 5 \mathrm{ml} \text { of cow's milk, } \\
\text { Half a piece of wet almond also rubs with Vacha Mula. } \\
\text { The product was mixed with } 5 \mathrm{ml} \text { of honey and give orally to CP } \\
\text { children. }\end{array}$ \\
\hline 2. & $\begin{array}{l}\text { Samvardhana Ghrita } \\
\text { (Duration=93 days) }\end{array}$ & $\begin{array}{l}\text { - Samvardhana Ghrita was taken from standard pharmaceutical } \\
\text { company of Ayurveda. } \\
\text { * Samvardhana Ghrita was prepared as per the recommendation of } \\
\text { Kashyapa Samhita }{ }^{24} \text { by Ghrita Paka method }{ }^{25} \text {. } \\
\text { * The dose of Samvardhana Ghrita was decided by using the criteria of } \\
\text { Sharangadhara Samhita }{ }^{26} \text {. }\end{array}$ \\
\hline
\end{tabular}




\section{Step - 2 Purva-Karma(preparatory procedures) (Total 10 days in each course of treatment)}

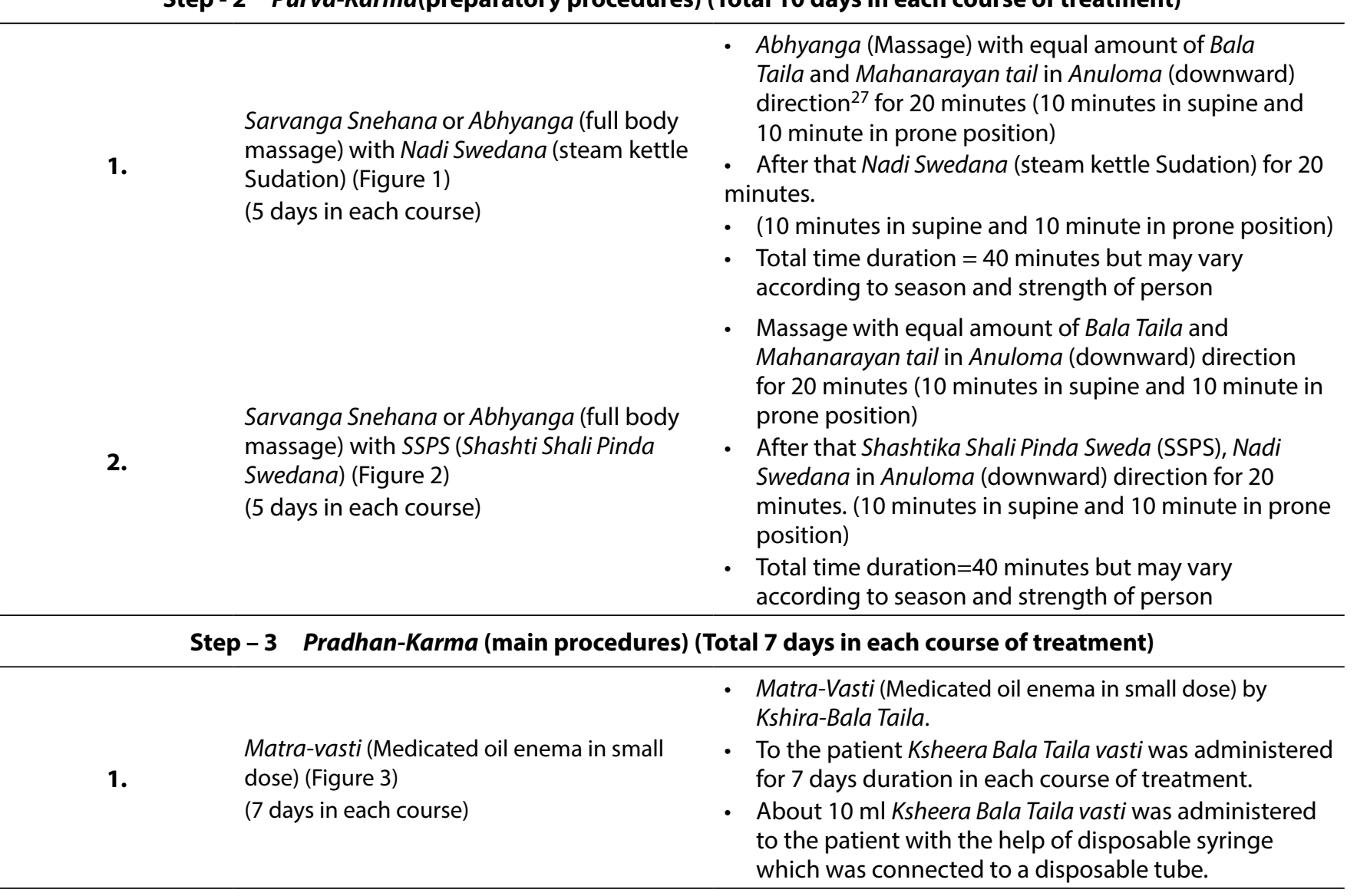
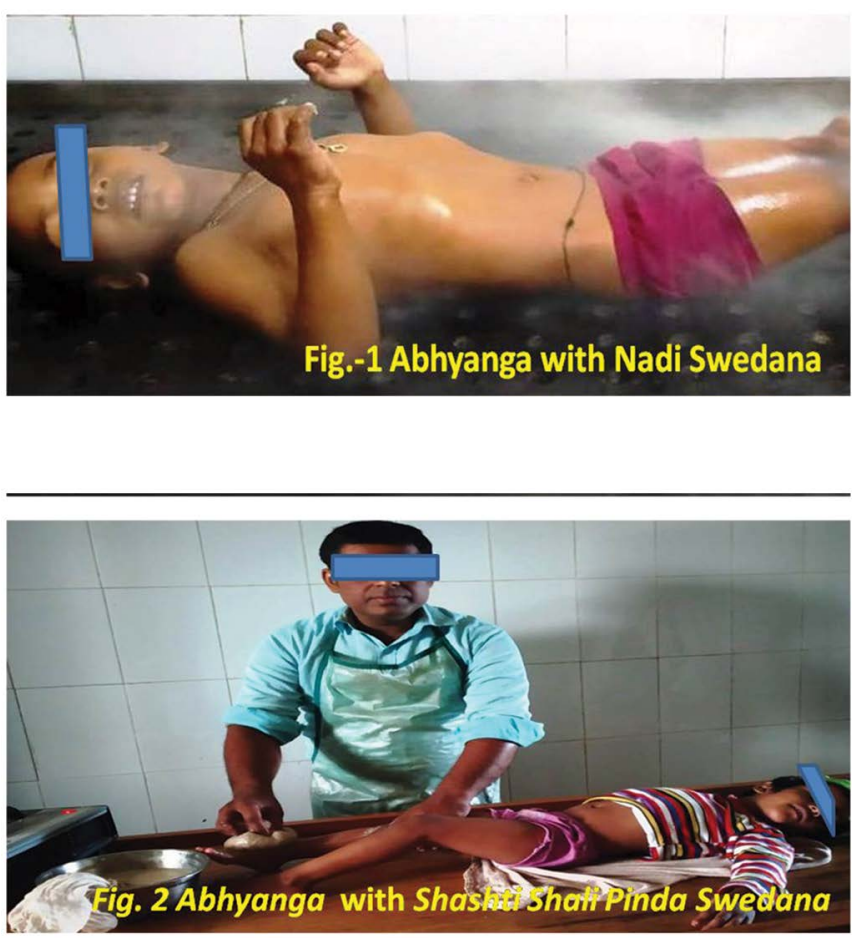

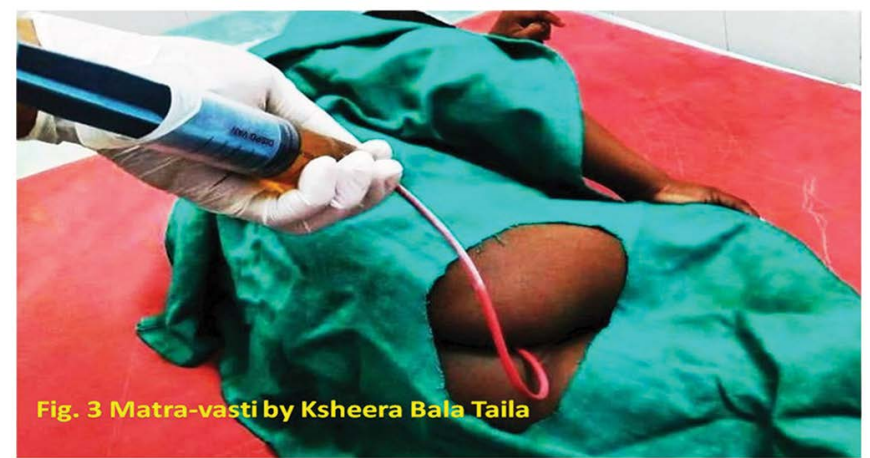

frequency and severity, muscle spasticity, power of muscle and QOL. Improvement in motor milestones assessment was done by milestone assessment criteria ${ }^{28}$, growth parameters by anthropometry, drooling frequency and severity by drooling assessment criteria ${ }^{29}$, muscle spasticity by modified Ashworth scale ${ }^{30}$, Muscle power by MRC Scale ${ }^{31}$ and QOL by MACS (Manual Ability Classification System) scale ${ }^{32}$. 


\section{Result}

Three courses (sittings) of treatment were completed in 93 days. After that significant improvement was found in all milestones such as speech (grade-2 to grade-1), verbal (grade-2 to grade-1) and able to walk with support (grade-3 to grade-2) (Chart 1). Weight, length, Head Circumference (HC), Chest Circumference (CC) and Mid Arm Circumference (MAC) was improved significantly (Chart 2 ) which indicates growth in patient. Muscle spasticity was reduced from grade- 4 to grade- 2 on modified Ashworth scale (Chart 3). Muscle power improved after treatment from grade- 1 to grade- 2 on Medical Research Council (MRC) Scale (Chart 3). Drooling frequency and drooling severity significantly improved after therapy (Chart 3). QOL was also improved in MACS scale (Chart 3).
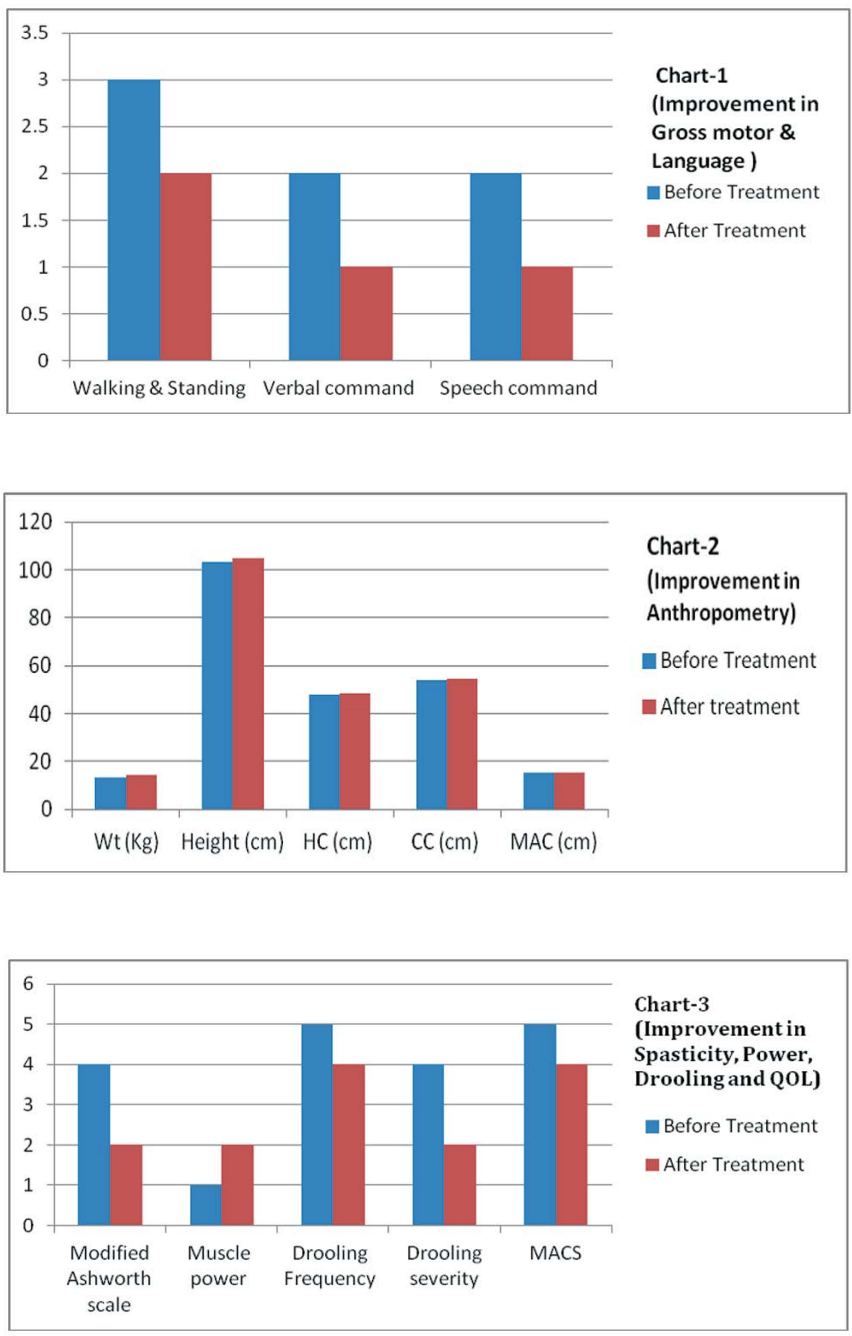

\section{Discussion}

Cerebral palsy is a syndrome rather than single disease. Cerebral palsy mainly affects movement and posture which arise due to injury of fetal or infant brain ${ }^{33}$. The etiology of cerebral palsy can be thought of using the four P's: prematurity, prenatal, pen natal and postnatal. Birth asphyxia is cause of cerebral palsy in this case study and this is most common cause of cerebral palsy in another study also ${ }^{34}$ Spastic CP is most common type and occurrence is about $70-75 \%$ of cases ${ }^{35}$. It is characterized by signs of upper motor neurons injury viz. hypertonia, spasticity exaggerated Deep Tendon Reflexes (DTR) and extensor plantar responses. Spastic cerebral palsy is of three types; quadriplegia, diplegia and hemiplegia. The studied case was spastic quadriplegia and it is secondary to hypoxic ischemic events.

There is no exact correlation found for cerebral palsy in Ayurvedic literature. However, in view of the etiology and clinical features, Cerebral palsy may be the result of Shiromarmabhighata (injury to brain) and can be considered as Vata dominant conditions or Vata Vyadhi (neurological disorders).

So the aim of treatment for $\mathrm{CP}$ was to pacify vitiated Vata dosha. In Ayurveda, Snehana (Oleation), Swedana (Sudation) and Vasti karma (Medicated enema) are main line of treatment for Vata Vikara or Vata related disorders (neurological disorders) $^{36}$. In management of CP till now there is no successful treatment in modern pediatrics but in Ayurveda, by appropriate oral medication with Panchakarma procedures (Five-fold measures of Biocleansing) can be an effective method.

\section{Effect of Oral Medication}

In the form of oral medication Samvardhana Ghrita and Vacha-mula (Root of Acorus calamus) was given for 93 days continuously.

\section{- Samvardhana ghrita}

Samvardhana ghrita contains Kashaya rasa (Astringent taste), Madhura rasa (sweet taste), Lavana rasa (Salty taste) and Madhura vipaka (Sweet-bio transformation or final outcome of digestion) which are opposite in property of Vata. Hence Samvardhana Ghrita helps in improving all parameters related to 
physical and mental health of CP patients. Samvardhana Ghrita have Guru-snigdha guna (Quality or properties), Brimhana property (increase body weight naturally, boost immunity of body and rejuvenate body), Medhya property (improve memory with intellect) and Tridosha shamaka (suppress Vata, Pitta and Kapha) property which are of very helpful in treatment of $\mathrm{CP}^{37}$.

\section{- Vacha Mula (Roots of Acorus calamus)}

Many studies have claimed that the Vacha-mula (roots of Acorus calamus) helps in subsiding neurological symptoms of brain ${ }^{38-40}$ and also have positive effects on memory disorder ${ }^{41}$. Root of Vacha is very effective in improving grasping power, speech performance (language milestones) ${ }^{42}$ and learning performance, by decrease brain lipid peroxide content ${ }^{43}$. Use of Ayurvedic medicine with honey enhances the potency and decreases its bitterness; thereby increasing its palatability ${ }^{44}$.

\section{- Effect of Purva-karma (Preparatory Procedures)}

In total duration of treatment, Purva-karma (preparatory procedures) was done in three sitting with 14 days interval after each sitting.

\section{- Sarvanga snehana / abhyanga (Whole Body Massage)}

Abhyanga (body massage) by oil provides nourishment due to its Snigdh, Mridu and Picchila Guna (Oily, soft and sticky quality). Vayu resides in Sparshnendriya which is situated in tvacha (skin). Abhyanga (Massage) on skin directly works on Vata to shift to normalcy. Bala Taila and Mahanarayan tail both have Vata shamak (suppress Vata) property. When Snehana (Oleation) and Swedana (Sudation) are done together then Dosha deflect from Shakha (peripheral system comprising blood, tissues, skin and Rasa (plasma) to Koshta (hollow organs and cavities of body or complete digestive system) and then Koshta dosha managed by Vasti karma (Medicated Enema). When Vata comes to normalcy then delayed milestones will shift to normal state ${ }^{45}$. Abhyanga (Oleation) manages hypertonic condition, improves muscle bulk and power in Cerebral palsy ${ }^{46}$.

\section{- Nadi Swedana (Tube Sweating)}

Swedana (Sudation) after Abhyanga (massage) help to remove Aavarana (obstruction of normal movement or hampered normal movement) and Srotorodha (Obstruction of channels). Swedana (Sudation) is very helpful in relieving muscle spasticity, improves joint movement and Range of Motion (ROM).

\section{- Shashtika Shali Pinda Swedana (SSPS)}

Shashtika Shali Pinda Sweda is a Brimhaniya Snehika Swedana (A type of sudation) performed by Shashtika Shali (Oryza Sativa Linn) with Dashamula decoction and milk. It has Kapha-Pitta-Vata shamak properties ${ }^{47}$. Shshtika Shali rice has the Snigdha and Laghu guna (oily and light-ness property) and Brihana Karma (Anabolic function), So SSPS is very useful in malnutrition of limbs. SSPS enhances physical consistency and increases the muscular strength.

\section{- Effect of Pradhan Karma (Main Procedures)}

During total duration of treatment Matra-vasti (Medicated oil enema in small dose) was done in all three sitting and 7 days in each sitting.

\section{- Matra-Vasti (Oil Enema in Small Dose)}

Vasti is most important Pradhan-karma to manage the Vata Dosha in treatment of Cerebral palsy. Short chain fatty acids of medicated oil reaches rectum, colon and direct diffusion property from epithelial cells to blood capillary where it shows generalized effect ${ }^{48}$. Vasti is restricted till the crawling age but Anuvasana vasti (oil enema) can be given from early infancy. Matra-vasti is having Balya (strengthening), Brimhana (nourishing) and Vatarogahara property. Matra-vasti provides nourishment to deeper tissues ${ }^{49}$. Ksheera Bala Taila vasti mainly improves motor functions such as sitting, standing, crawling and walking in cerebral palsy patients. Fine and gross motor functions of cerebral palsy were improved by Vasti karma. Matra- Vasti found beneficial in spastic diplegia ${ }^{50}$.

\section{Total Effect of Therapy}

Total effect was found near 15-20\% improvement and this improvement helps the patient to improve QOL. Previously it was believed that neurons do not repair after any injury, but the new concept of neuroplasticity has mentioned that CNS have the ability to repair their 
neurons by axonal budding to take over the function of injured neurons. This improvement in cerebral palsy patients also supports the new concept of neuroplasticity.

\section{Conclusion}

Cerebral palsy is a multi-factorial disease. Ayurveda consider cerebral palsy as Vata-Vikara or Vata-Vyadhi (neurological disorders), occurring as a result of Shiromarmabhighata (injury to brain). The preferred treatment protocol is effective in reliving the symptoms of cerebral palsy patient. Combination of oral medication (Vacha mula and Samvardhana Ghrita) Purva-Karma (Abhyanga by equal amount Bala Taila and Mahanarayan along with Nadi Swedana \& Shashti Shali Pinda Swedana) and Pradhan-Karma (Ksheera Bala Taila Matra-vasti) was very effective for spastic cerebral palsy due to birth asphyxia.

\section{References}

1. Dunn PM. Dr William Little (1810-1894) of London and cerebral palsy. Archives Disease Child Fetal Neonatal. 1995 May; 72(3):F209-10. https://doi.org/10.1136/fn.72.3.F209. PMid:7796244. PMCid:PMC2528439

2. Sahoo R, Rege S, Rao S. Social participation in children with cerebral palsy. The Online Journal of Health and Allied Sciences. 2017; 16(4):5.

3. Bhinde SM. A case study on the Ayurvedic management of cerebral palsy. Ancient Sci Life. 2015; 34(3):167-70. https://doi.org/10.4103/0257-7941.157163. PMid:26120232. PMCid:PMC4458908

4. Shailaja U, Jain CM. Ayurvedic approach towards cerebral palsy. Ayu. 2009; 30(2):158-63.

5. Bass N. Cerebral palsy and neurodegenerative disease. Curr opin Pediatar. 1999; 8047.

6. Right diagnosis.com. Health Grades Inc.; c2011 [Internet]. [cited 2013 Jan 22]. Available from: http//www.rightdiagnosis.com/c/cerebral_palsy/stats-country.htm.

7. Kurubar AD, Munnoli BT, Kumar DV, Aziz A, Amol P. Role of Matra Basti (Enema) over Abhyanga (Massage) and Sweda (Sudation in reducing Spasticity in Cerebral Palsy with Shuddha Bala Taila-A. Randomized Comparative Clinical Study. International Journal of Ayurveda and Pharma Research. 2014; 2(2):47-52.

8. Med India. Kathy Jones: Incidence of Cerebral Palsy Remains Constant in India on Indian Health News, Inc.; c19972013 [Internet]. [2013 Jan 22]. Available from: http://www. medindia.net/news/Incidence-of-Cerebral-Palsy-RemainsConstant-in-India-74912-1.htm.
9. Boyle CA, Yeargin-Allsopp M, Doernberg NS, Holmgreen P, Murphy CC, Schendel DE. Prevalence of selected developmental disabilities in children 3-10 years of age: The Metropolitan Atlanta Developmental Disabilities Surveillance Program 1991. MMWR CDC Surveill Summ. 1996; 45:1-14.

10. Nair MKC, Babu G, Padmamohan J, Sunitha RM, Resmi VR, Prasanna GL, Leena ML. Developmental delay and disability among under - 5 children in a rural ICDS block. Indian Pediatrics. 2009; 46:75-8.

11. Shailaja U, Jain CM. Ayurvedic approach towards Cerebral Palsy. AYU. 2009; 30(20):158-63.

12. Chaitanya A. Effect of ksheera vasti in the management of spastic cerebral palsy in infant - A case study. International Ayurvedic Medical Journal. 2015; 3(10).

13. Laptook AR, Shankaran S, Tyson JE, Munoz B, Bell EF, Goldberg RN et al. Effect of therapeutic hypothermia initiated after 6 hours of age on death or disability among newborns with hypoxic-ischemic encephalopathy. Journal of the American Medical Association. 2017; 318(16):1550-60.

14. Polak F, Morton R, Ward C, Wallace WA, Doderlein L, Siebel A. Double-blind comparison study of two doses of botulinum toxin A injected into calf muscles in children with hemiplegic cerebral palsy. Developmental Medicine \& Child Neurology. 2002 Aug; 44(8):551-5. https://doi. org/10.1111/j.1469-8749.2002.tb00328.x

15. Butler C, Campbell S. Evidence of the effects of intrathecal baclofen for spastic and dystonic cerebral palsy. AACPDM Treatment Outcomes Committee Review Panel. Developmental Medicine and Child Neurology. 2000 Sep; 42(9):634-45. https://doi.org/10.1017/S0012162200001183. PMid:11034458

16. HBO Treatment.com [Internet]. Available from: www. hbotreatment.com.

17. Farmer JP, Sabbagh AJ. Selective dorsal rhizotomies in the treatment of spasticity related to cerebral palsy. Child's Nervous System. 2007 Sep; 23(9):991-1002. https://doi. org/10.1007/s00381-007-0398-2. PMid:17643249

18. Available from: http://www.en.wikipedia.org/wiki/ Neuroplasticity.

19. Meena MK, Mukhopadhyay B, Singh BM. Role of traditional therapy protocols with samvardhana ghrita on language development in cerebral palsy children. Int J Ayurveda \& Med Sc. 2016; 1(3):56-62.

20. Shailaja U, Rao PN, Girish KJ, Arun Raj GR. Clinical study on the efficacy of Rajayapana Basti and Baladi Yoga in motor disabilities of cerebral palsy in children. Ayu. 2014; 35:294-9. https://doi.org/10.4103/0974-8520.153748. PMid:26664239. PMCid:PMC4649573

21. Rushikesh VT, Kulkarni R, Shailaja U, Nithin SA, Mallanvar V, Nayankumar S, Yogesh VT. Nutritional deficiency disorders in pediatrics: An Ayurvedic perspective. International 
Journal of Research in Ayurveda and Pharmacy. 2013; 4(4):605-7. https://doi.org/10.7897/2277-4343.04431

22. Raj GRA, Viswaroopan D, Shailaja U, Kumar KMR, Pujar MP. A review on cerebral palsy in children: Bridging Ayurvedic concepts with scientific approaches in medicine. International Journal of Research in Ayurveda and Pharmacy. 2017; 8(1):26-7. https://doi.org/10.7897/2277-4343.0817

23. Shailaja U, Rao PN, Girish KJ, Raj GRA. Clinical study on the efficacy of Rajayapana Basti and Baladi Yoga in motor disabilities of cerebral palsy in children. Ayu. 2014; 35:294-9. https://doi.org/10.4103/0974-8520.153748. PMid:26664239. PMCid:PMC4649573

24. Sharma PH, Rajaguru. Kashyap Samhita or Vrddhajivakiya Tantara, Sutra Sthana; Leha-Adhyaya: Chapter 18 verse 35-36; p. 6.

25. Tripathi B. Sharngadhara-Samhita, Madhyam Khand; Sneh-PakaVidhi: Chapter 9, verse1; Varanasi: Chaukhamba Sanskrit prakashan; 2006. p. 218.

26. Tripathi B. Sarngadhara Samhita, Purvakhand; Aharaadhigatikathanama: Chapter 6, verse 49-50; Varanasi: Chaukhamba Sanskrit prakashan; 2006. p. 84.

27. Kasture SD. Ayurvediya panchkarama vigayanam, Chapter 2, Shri Viadhiya nath Ayurveda bhavan limited; 2011. p. 83.

28. Shailaja U, Rao NP, Raj GRA. Clinical study on the efficacy of Samvardhana ghrita orally and by matrabasti in motor disabilities of cerebral palsy in children. International Journal of Research in Ayurveda and Pharmacy. 2013; 4(3):373-7. https://doi.org/10.7897/2277-4343.04313

29. Lee Z-I, Cho D-H, Choi W-D, Park D-H, Byun S-D. Effect of botulinum toxin Type A on morphology of salivary glands in patients with cerebral palsy. Annals of Rehabilitation Medicine. 2011; 35(5):636-40. https://doi.org/10.5535/arm.2011.35.5.636. PMid:22506185. PMCid:PMC3309260.

30. Available from: http://www.physiotherapy-treatment.com/ modified-ashworth-scale.html.

31. Santosh K. Pediatric Clinical Examination. 2nd ed. Hyderabad: Paras Medical Publisher; 2010. p. 232

32. Carnahan KD, Arner M, Hägglund G. Association between Gross Motor Function (GMFCS) and Manual Ability (MACS) in children with cerebral palsy. A population-based study of 359 children. BMC Musculoskelet Disord. 2007; 8:50. https://doi.org/10.1186/1471-2474-8-50. PMid:17584944. PMCid:PMC1919364

33. Swaiman KF, Russman BS. Cerebral palsy. Pediatric Neurology: principles and practice, 3rd edition. St. Louis Mosby; 1999. p. 312-24.

34. Vyas AG, Kori VK, Rajagopala S, Patel KS. Etiopathological study on cerebral palsy and its management by Shashtika Shali Pinda Sweda and Samvardhana Ghrita. Ayu. 2013 Jan-Mar; 34(1):56-61. https://doi.org/10.4103/0974-8520.115450. PMid:24049406. PMCid:PMC3764881.
35. Chaitanya A. Effect of ksheera vasti in the management of spastic cerebral palsy in infant - A case study. International Ayurvedic Medical Journal. 2015; 3(10).

36. Singh K, Verma B. Ayurvedic perspectives towards Cerebral palsy. Journal of Research and Education in Indian Medicine. 2012; 18(3-4):163-74.

37. Shailaja U, Rao NP, Raj GRA. Clinical study on the efficacy of Samvardhana ghrita orally and by Matrabasti in motor disabilities of cerebral palsy in children. International Journal of Research in Ayurveda and Pharmacy. 2013; 4(3):373-7. https://doi.org/10.7897/2277-4343.04313

38. Howes MR. Plants used in Chinese and Indian traditional medicine for improvement of memory and cognitive function. Houghton. Pharmacology Biochemistry and Behavior. 2003; 75:513-27. https://doi.org/10.1016/S0091-3057(03)00128-X

39. Sala AV, Warrier PK, Nambiar VP, Ramankutty C. Indian Medicinal Plants: A Compendium of 500 Species, 1. Sangam Books Limited, London; 1993.

40. Hou JP, Jin Y. The healing power of Chinese. Herbs and Medicinal Recipes. The Haworth Integrative Healing Press, Binghampton, New York; 2005.

41. Mukherjee PK, Wahile A. Integrated approaches towards drug development of Ayurveda and other Indian system of medicines. Journal of Ethnopharmacology. 2006; 103:25-35. https://doi.org/10.1016/j.jep.2005.09.024. PMid:16271286

42. Vihra S, Shah S, Dandiya P. Central nervous system studies on an ethanol extract of Acorus calmus rhizomes. Journal of Ethnopharmacology. 1990; 28:53-62. https://doi. org/10.1016/0378-8741(90)90065-2

43. Manikandan S, Srikumar R, Jeya PN, Sheela DR. Protective effect of Acorus calamus Linn on free radical scavengers and lipid peroxidation in discrete regions of brain against noise stress exposed rat. Bio Pharma Bull 2005; 28:2327-30. https:// doi.org/10.1248/bpb.28.2327. PMid:16327175

44. Gupta P, Tripathi A, Agrawal T, Narayan C, Singh BM, Kumar M, et al. Synergistic Experimental Biology. 2016; 54: 530-6.

45. Bhinde SM, Patel KS, Kori VK, Rajagopala S. Management of spastic cerebral palsy through multiple Ayurveda treatment modalities. AYU. 2014; 35(4):462-6. https:// doi.org/10.4103/0974-8520.159044. PMid:26195914. PMCid:PMC4492036.

46. Rathia S, Kori VK, Rajagopala S, Patel KS, Chaudhary SA. A clinical study to assess the effect of samvardhana ghrita and yoga basti in cerebral palsy. Pharma Science Monitor. 2015; 6(4):108-17.

47. Sushruta. Sushruta samhita, English translation by Sharma P.V, Vol I, Sutra sthan (38:71), Chaukhambha Vishvabharati, Varanasi; 2005.

48. Choudhary KR. Recent advances in Ayurvedic management of cerebral palsy affected children. International Journal of 
Research in Ayurveda and Pharmacy. 2014; 5(6):642-7. https://doi.org/10.7897/2277-4343.056131

49. Sohini S, Anirudhan R. Conventional Ayurvedic Management in Spastic Cerebral Palsy: A Case Study. International Journal of Ayurveda and Pharma Research. 2015; 5(4):38-41.
50. Shailaja U, Rao NP, Raj GRA. Clinical study on the efficacy of Samvardhana ghrita orally and by Matrabasti in motor disabilities of cerebral palsy in children. International Journal of Research in Ayurveda and Pharmacy. 2013; 4(3):373-7. https://doi.org/10.7897/2277-4343.04313 